\section{Effects of substrate and ectomycorrhizal inoculation on the development of two- years-old container-grown Norway spruce (Picea abies Karst.) seedlings}

\author{
Ivan Repáč, Miroslav Balanda, Jaroslav Vencurik, Jaroslav Kmet', Diana \\ Krajmerová, Ladislav Paule
}

The objective of this study was to test the effects of selected peat growth substrates (Agro CS, Gramoflor and Durpeta) and inoculation with commercial ectomycorrhizal inocula (Ectovit and Mycorrhizaroots) on growth, ectomycorrhiza formation, needle nutrients concentration and several physiological parameters of two-years-old containerized Norway spruce seedlings cultivated under standard nursery conditions. The selected substrates differed in origin, composition and nutrient content: Agro CS and Gramoflor were mixtures of various peat types and components with added nutrients, while Durpeta was non-enriched pure peat. Growth parameters of seedlings cultivated in enriched substrates were significantly higher than those grown on the non-enriched substrate. Significant interactions were found between substrate and inoculation treatments. Inoculation with Ectovit stimulated seedling growth in non-enriched substrate but had no effect on seedling parameters in the enriched substrates, and a negative effect on aboveground biomass in Gramoflor. Mycorrhizaroots inoculum significantly decreased shoot to root dry weight ratio, but had no other effect on seedling development. ECM colonization rate of seedlings ranged from 73 to $80 \%$, with no significant effects of the ECM inoculum or growth substrate. DNA analysis revealed a low species diversity of ECM fungi on seedling roots, with a pronounced dominance of the soil-borne ECM species Thelephora terrestris Fr. Chemical analysis of needles and measurement of chlorophyll $a$ fluorescence showed similar trends as seedling growth. Values of chlorophyll $a$ fluorescence parameters and needle $\mathrm{N}, \mathrm{P}, \mathrm{K}, \mathrm{Ca}$ and $\mathrm{Mg}$ concentrations were higher in both enriched substrates. Ectovit increased (though not significantly) chlorophyll $a$ fluorescence in needles as compared to Mycorrhizaroots- and non-inoculated seedlings, as well as nutrient-uptake (mainly $K$ ) in the non-enriched substrate. Our results suggest the importance of the origin and composition of peat-based substrates on the development of containergrown Norway spruce seedlings, while the observed positive effect of the commercial ECM inoculum Ectovit was more probably caused by its physical and chemical properties rather than by its efficiency in promoting ECM fungi symbiosis. The enriched substrates tested appear to be suitable for production of spruce seedlings of acceptable size for outplanting within two growing seasons.

Keywords: Peat Substrate, Ectomycorrhizal Inoculation, Norway Spruce, Container-grown Seedlings, Nutrition, Chlorophyll $a$ Fluorescence, DNA Analysis

\footnotetext{
Introduction

Norway spruce (Picea abies [L.] Karst.) is ecologically and economically the most important coniferous tree species in Slovakia. Planting stock is predominantly produced as bareroot transplanted seedlings in a 3-5 year nursery rotation. The proportion of container-grown spruce seedlings is still only about $6 \%$ of the total production (15 million of spruce seedlings of plantable size annually), though the advantages of container as compared with bareroot stock are wellknown, e.g., better root protection, ameliorative and nutrient effects of potting substrate,
}

reduction of transplanting stress on planting site. Other advantages include more effective care for and faster growth of seedlings grown individually in containers (especially under greenhouse conditions) than bareroot seedlings grown in dense spacing in a nursery bed (Nilsson \& Orlander 1995). The better survival of containerized stock, especially on adverse planting sites (Wilson et al. 2007, Repáč et al. 2011a, Esen et al. 2012) warrants the increased use of this material and the improvement of nursery practices of container-grown seedlings production.

The development of container-grown seed-
Technical University in Zvolen, T. G. Masaryka 24, SK 96053 Zvolen (Slovak Republic)

(a) Ivan Repáč (repac@tuzvo.sk)

Received: Mar 17, 2014 - Accepted: Aug 14, 2014

Citation: Repáč I, Balanda M, Vencurik J, Kmet' J, Krajmerová D, Paule L, 2014. Effects of substrate and ectomycorrhizal inoculation on the development of twoyears-old container-grown Norway spruce (Picea abies Karst.) seedlings. iForest 8: 487-496 [online 2014-11-10] URL:

http://www.sisef.it/iforest/contents/? id=ifor $1291-007$

Communicated by: Silvano Fares

lings in forest nurseries is affected by many factors. Besides type and size of container (South et al. 2005, Topić et al. 2006), potting medium plays an important role (Bernier \& Gonzalez 1995, Heiskanen 2013). One of the growth media most utilized for growing containerized plants is peat, used either alone or as a main component of peatbased growing mixtures (Landis et al. 1990, Vaario et al. 2009, Heiskanen 2013). Especially light low-humified Sphagnum peat has the required attributes (such as low $\mathrm{pH}$, high cation exchange capacity, low inherent fertility, a proper balance of aeration and waterholding porosity) and provides reasonable growth conditions in the greenhouse (Landis et al. 1990, Heiskanen 1993). Nevertheless, an admixture of proper components and fertilizers to pure peat can improve its physical (Heiskanen 1993, 1995) and chemical properties (Juntunen \& Rikala 2001, Fan et al. 2004), and as a consequence, promote the growth and physiological quality of seedlings (Bernier \& Gonzalez 1995, Bakry et al. 2013). In Slovakia, peat is generally used as a growth substrate for production of container-grown seedlings. In recent years, nursery managers began using peat substrates of various composition from foreign producers, mainly from central European and Baltic countries.

Growing substrate and fertilization can also influence the amount and composition of seedlings' ectomycorrhizae in forest nurseries (Gonzalez-Ochoa et al. 2003, Rincón et al. 2005, Repáč 2007, Vaario et al. 2009). In certain circumstances, ECM symbiosis can increase water and nutrient uptake, tolerance to adverse soil conditions or reduce the effects of soil-borne pathogens on trees (Marx et al. 1976, Kropp \& Langlois 1990, Courty et al. 2010). Successful ECM inoculation of seedlings in the forest nursery can promote their subsequent adaptation and growth on 
the planting site (Garbaye \& Churin 1997, Ortega et al. 2004). Several types of natural and laboratory produced inocula and application techniques have been used for seedal. 1988, Repáč 2011). Production and application of ECM inocula on a commercial scale are increasingly expanding worldwide. Several authors were concerned about the effects of inoculation by ECM fungi on ectomycorrhiza formation, physiology and/or growth of Norway spruce seedlings in aseptic (Ineichen \& Wiemken 1992, Rincón et al. conditions (Le Tacon et al. 1986, Lehto 1994, Vodnik \& Gogala 1994, Repáč 1996, 2007, Brunner \& Brodbeck 2001). Reported results are inconsistent; positive effects of application of ECM fungi were not found in all cases. In Slovakia, laboratory produced mycelial inocula of ECM fungi were applied and their effects estimated in small nursery experiments (Repáč 1996, 2007, Repáč et al. 2011b). Commercial ECM inoculation on a larger scale has been recently carried out in the state-owned nurseries in Slovakia, but the performance of inoculation on seedling development has not been estimated.

The objective of this study was to test the effects of selected peat growth substrates and inoculation with commercial ectomycorrhizal inocula Ectovit and Mycorrhizaroots on growth, ectomycorrhiza formation, needle nutrients concentration and several physiological parameters of two-years-old containergrown Norway spruce (Picea abies Karst.) seedlings cultivated under standard operational conditions.

\section{Material and methods}

\section{Experimental design}

The experiment was carried out in a greenhouse and outdoor bed under operational conditions in a state-owned nursery located in northern Slovakia $\left(49^{\circ} 06^{\prime} 27^{\prime \prime} \mathrm{N}, 19^{\circ} 44^{\prime}\right.$ $54^{\prime \prime}$ E, altitude $830 \mathrm{~m}$ a.s.1.). Norway spruce seedlings were grown in plastic trays containing 81 cavities (Plantek 81F, Lännen Plant Systems - BCC Oy, Säkylä, Finland - each cavity $85 \mathrm{~cm}^{3}$, depth $73 \mathrm{~mm}$, top $41 \times 41 \mathrm{~mm}$, 549 cavities $\mathrm{m}^{-2}$ ) filled with three substrates (Agro CS RS2 - Agro CS a.s., Česká Skalice, Czech Republic; Gramoflor Cocofibre G-SG - Gramoflor GmbH \& Co. KG, Vechta, Germany; Durpeta - UAB Durpeta, Kuling inoculation (Marx et al. 1976, Mortier et 2003, Vaario et al. 2010) and operational

piškio, Lithuania). Two commercial ectomycorrhizal inocula treatments were applied (Ectovit ${ }^{\circledR}$, Symbiom s.r.o., Lanškroun, Czech Republic; and MycorrhizaRoots ${ }^{\circledR}$, Lebanon Turf, Lebanon, Pennsylvania, USA), along with one non-inoculated control. The experiment was arranged as a completely randomized block design of 9 combinations of main effects (3 substrate $\times 3$ inoculation treatments) repeated three times ( 3 blocks). One repetition of each treatment combination consisted of 4 trays (324 cavities), thus the experiment consisted of $324 \times 3$ (substrate) $\times 3$ (inoculation) $\times 3$ (block) $=8.748$ seedlings (containers) in total.

\section{Substrates, commercial ectomycorrhizal} inocula and inoculation

The main component of all substrates was peat. The substrates were different in origin (peatbog), degree of decomposition, structure, additives composition, nutrient content and other properties. The distinctive difference among the substrates was that Agro CS and Gramoflor were diverse in composition and artificially-nutrient-enriched, while Durpeta was non-enriched pure natural peat. Composition of Agro CS substrate (RS2 for

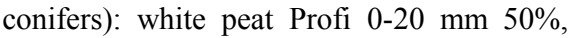
Unguri peat $5-10 \mathrm{~mm} 20 \%$, black peat $0-20$ $\mathrm{mm} 20 \%$, coconut fibre $10 \%$, Bentonit $15 \mathrm{~kg}$ $\mathrm{m}^{-3}$, Multicote $4 \mathrm{M}$ (NPK $18-6-12 \%+\mathrm{Mg}$ $2 \%+$ micro-elements) $2 \mathrm{~kg} \mathrm{~m}^{-3}$, PG Mix (macro- and micro-elements set) $1 \mathrm{~kg} \mathrm{~m}^{-3}$, Fibazorb $0.11 \mathrm{~m}^{-3}$. Composition of Gramoflor substrate (Cocofibre G-SG): white peat from north Germany (digging in peat-block form) $0-20 \mathrm{~mm} 70 \%$, peat fibre $20-40 \mathrm{~mm}$ $15 \%$, coarse coconut fibre $15 \%$, clay $10 \%$ of weight $\left(30 \mathrm{~kg} \mathrm{~m}^{-3}\right)$, Kompakt (NPK 21-7$14 \%+$ micro-elements) $0.8 \mathrm{~kg} \mathrm{~m}^{-3}$, Radigen (micro-elements set) $100 \mathrm{~g} \mathrm{~m}^{-3}$, Triplephosfat $46 \% 200 \mathrm{~g} \mathrm{~m}^{-3}$, keratin $3 \mathrm{~kg} \mathrm{~m}^{-3}$, detergent $900 \mathrm{ml} \mathrm{m}^{-3}$. Durpeta substrate was a natural dark (brown) low-bog type peat without any kind of additives, middle segmented (decomposed), fibre size $0-20 \mathrm{~mm}$, harvested in the Šepeta peatbog, northeastern Lithuania. The substrates were analyzed for basic chemical parameters prior to inoculation (Tab. 1). Analysis of physical properties of the substrates was not done.

Ectomycorrhizal inoculum Ectovit contains mycelium of four ECM fungi (Cenococcum geophilum, Hebeloma velutipes, Laccaria proxima and Paxillus involutus) and basidio-

Tab. 1 - Analytical parameters of peat-based substrates ( $n=1$ combined sample) used for cultivation of container-grown Norway spruce seedlings inoculated with commercial ectomycorrhizal inocula Ectovit and Mycorrhizaroots.

\begin{tabular}{|c|c|c|c|c|c|c|c|c|}
\hline Substrate & $\mathrm{pH}_{\mathrm{H} 2 \mathrm{O}}$ & $\begin{array}{c}\mathrm{C} \\
(\%)\end{array}$ & $\begin{array}{c}\mathrm{N} \\
(\%)\end{array}$ & $\mathbf{C} / \mathbf{N}$ & $\begin{array}{c}\mathbf{P} \\
\left(\mathrm{mg} \mathrm{kg}^{-1}\right)\end{array}$ & $\begin{array}{c}\mathrm{K} \\
\left(\mathrm{mg} \mathrm{kg}^{-1}\right)\end{array}$ & $\begin{array}{c}\mathrm{Ca} \\
\left(\mathrm{mg} \mathrm{kg}^{-1}\right)\end{array}$ & $\begin{array}{c}\mathrm{Mg} \\
\left(\mathrm{mg} \mathrm{kg}^{-1}\right)\end{array}$ \\
\hline AgroCS & 4.35 & 35.2 & 0.90 & 39 & 42 & 932 & 2276 & 964 \\
\hline Gramoflor & 4.62 & 33.3 & 0.89 & 37 & 48 & 879 & 2632 & 835 \\
\hline Durpeta & 3.36 & 46.9 & 0.95 & 49 & 37 & 1010 & 1648 & 640 \\
\hline
\end{tabular}

spores of two fungi (Pisolithus arrhizus and Scleroderma citrinum). The spores are dispersed in a peat-based carrier together with ingredients supporting the development of ectomycorrhizae (humates, ground minerals, extracts from sea organisms) and naturally degradable particles of a water-retaining gel. Ectovit was applied as slurry (gel) that was prepared by mixing fungal mycelium with dry components of inoculum (including fungal spores and a powder hydrogel) and an adequate amount of water. The slurry was thoroughly mixed with the growing substrates at a ratio $1: 5(\mathrm{v}: \mathrm{v})$. The containers were filled with this mixture immediately before sowing. The inoculum-substrate mixture contained $0.32 \mathrm{ml}$ of mycelium in each cavity. The amount of spores in Ectovit was not known. Viability of mycelium of all four fungi entrapped in Ectovit was determined by cultivating pure fungal cultures on agar BAF medium (Moser 1960) in sterile conditions. No additional tests for inoculation efficiency of both inocula used were carried out.

MycorrhizaRoots contains spores of ECM fungi Pisolithus tinctorius (1 600000 dry spores per gram), four species of Rhizopogon (80 000 spores $\mathrm{g}^{-1}$ of each species), two species of Scleroderma $(40000)$ and two species of Laccaria (16 000), plus vasiculoarbuscular fungi Glomus (8 species) and $\mathrm{Gi}$ gaspora margarita (the proportion of all spores in inoculum was $23.3 \%$ of the inoculum weight), humic acid (28.9\%), cold water kelp extracts $(18.0 \%)$, ascorbic acid (vitamin C - 12.3\%), amino acids (glycine - 8.5\%), myo-Inositol $(3.5 \%)$, maltodextrin $(2.25 \%)$, thiamine (vitamin $\mathrm{B}_{1}-2.0 \%$ ), alpha-tocopherol (vitamin E - 1.0\%) and surfactant $(0.25 \%)$. Substrates in the containers were inoculated with a water solution of Mycorrhizaroots $\left(0.8 \mathrm{~g}^{-1}\right)$ to wet the root zone thoroughly (approximately $31 \mathrm{~m}^{-2}$ ) 2 weeks after seedling emergence and once more in the middle of July (approximately in the middle of the first growing season). Irrigation was suspended for a period to avoid run-off of the inoculum.

\section{Seeds and seedlings}

Seeds of Norway spruce were collected from a source in northen Slovakia (selected mature stand certified for seed collection according to Slovakia rules, altitude $900 \mathrm{~m}$ a.s.l., certificate number SK-1049/2010). Seeds were washed in tap water, then sterilized $15 \mathrm{~min}$ in $30 \% \mathrm{H}_{2} \mathrm{O}_{2}$, rinsed repeatedly with distilled water, dried at room temperature and then treated with powder fungicide Dithane M-45 (Rohm and Haas, Vienna, Austria), at $1 \%$ of seed weight. In the middle of April, immediately after filling containers with substrates, one seed was sown in each cavity and covered with a thin layer of perlite. Trays were placed $15 \mathrm{~cm}$ above the 
greenhouse floor on pallets. Seedlings were grown under natural light and ambient temperatures. Maximum air temperature was controlled during hot days by ventilation. The substrates were irrigated (1-2 times per day) to maintain adequate humidity (approximately $50-70 \%$ according to germination and growing phase). Air humidity was not controlled.

Starting since three weeks after the beginning of their emergence, seedlings were supplied twice per week with $0.3 \%$ solution of fertilizer (Superex ${ }^{\circledR}$, NPK 19-4-20\% + microelements $\mathrm{Mg}, \mathrm{B}, \mathrm{Co}, \mathrm{Cu}, \mathrm{Fe}, \mathrm{Mn}, \mathrm{Mo}$ Zn, S, Kekkilä Oy, Vantaa, Finland) for the first 3 weeks, and with $0.45 \%$ solution of Superex for the next 8 weeks. Fertilizer was applied through the nursery irrigation system. Fungicides Dithane ${ }^{\circledR}$ (Rohm and Haas, Vienna, Austria) and Novozir ${ }^{\circledR}$ (Dow AgroSciences, Lauterbourg, France) were applied alternately at 10-day intervals until the greenhouse polyethylene cover was removed, and then at 2-week intervals until the end of August to avoid damping off and other pathogen diseases. The greenhouse polyethylene cover was removed 8 weeks af ter seedling emergence. At the end of the first growing season (end of October), seedlings were placed on an open bed (hardening area) for overwintering and remained there throughout the second growing season. The trays were packed with sawdust around the sides and underneath to prevent frost damage. The substrate surface was also covered with a thin layer of sawdust. The seedlings were manually weeded and irrigated as needed and fertilized with $2 \%$ solution of Supere ${ }^{\circledR}$ via irrigation system during the second growing season. The time of fertilizer application after the greenhouse cover was removed varied according to the incidence of rainfall.

\section{Sampling, measurements and data analyses}

In August of the second growing season, chlorophyll a fluorescence of needles was measured on 12 seedlings from each treatment combination and block ( 3 seedlings per tray, 324 seedlings totally) using a chlorophyll fluorimeter (Handy Pea fluorimeter, Hansatech Ltd, Kings Lynn, UK). Needles were irradiated by one-second-long saturating pulse $\left(2000 \mu \mathrm{mol} \mathrm{m}^{-2} \mathrm{~s}^{-1}\right)$ after a $30-\mathrm{min}$ long dark adaptation period. The following parameters were measured: $F 0$ (initial fluorescence - all reaction centers are open), $\mathrm{Fm}$ (maximum fluorescence - all reaction centers are closed), $F v=F m-F 0$ (variable fluorescence), $F v / F m$ (maximal photochemical efficiency of PSII), Tfm (time of reaching maximum fluorescence), Area (area above the fluorescence curve), $R C / A B S$ (density of reaction centers), $F v / F O$ (competitive non-photochemical processes in PS II in dark-adap- ted state), $V j$ (relative variable fluorescence at time $2 \mathrm{~ms}$ after start of light pulse) and $P I$ (Performance index for the photochemical activity - Brestič \& Zivčák 2013).

After the second growing season (end of October), 20 dormant seedlings from each treatment combination and block (5 seedlings per tray, overall 540 seedlings) were randomly selected for estimation of ectomycorrhiza formation, growth, and chemical analysis (nutrient concentration) of the photosynthetic tissue (needles). Stem height, root collar diameter $(R C D)$, and shoot and root dry weights $(S D W$ and $R D W$, respectively - $48 \mathrm{~h}$ at $80{ }^{\circ} \mathrm{C}$ ) were recorded for each seedling. Total dry weight $(T D W)$ and ratio of shoot and root dry weights $(S D W /$ $R D W$ ) were calculated.

Number of root tips, morphology and percentage of ectomycorrhizae were estimated on four randomly selected seedlings for each treatment combination and block. Seedlings were stored at $4{ }^{\circ} \mathrm{C}$ and analyzed within two days after lifting. The root system was removed free of soil and gently washed in tap water. Root tips were examined and counted on the long (10-15 cm approx.) lateral roots of each seedling at $\times 10-40$ magnification by a dissecting microscope. Root tips were determined as ectomycorrhizae and classed into ECM morphotypes on the basis of gross morphological characteristics such as ramification, shape, color, outer mantle characteristics, presence of hyphae and rhizomorphs (Agerer 2002, Agerer \& Rambold 2011). To confirm the formation of ectomycorrhizae, suspected short roots were cut repeatedly and examined by light microscopy (magnification $\times 400-800$ ). Root cross-sections were cut and stained with cotton blue before microscopic observation. Presence of a complete fungal mantle (hyphae entirely surrounded a periphery of the section), irrespective of its thickness, and a Hartig net with hyphae intercellulary penetrating at least two layers of cortical cells, were considered as evidence of ectomycorrhizae (Repáč 2007).

The number of ectomycorrhizae within each ECM morphotype along with the nonmycorrhizal root tips were counted for each seedling. The percentage of each ECM morphotype was determined as a percent portion of the number of ectomycorrhizae of respective morphotype from the total number of root tips (all ectomycorrhizae + non-mycorrhizal root tips). Total ECM colonization was calculated as a sum of percentages of the ECM morphotypes.

On the basis of distinctive specific morphological characteristics, one of three distinguished ECM morphotypes was identified on a species level, though molecular analysis of such morphotype was not carried out. Due to the absence of reliable identifying morphological features and mutual morphological similarity, it was not possible to visually identify the other two ECM morphotypes. Their identification was done by sequencing of the ITS region of ribosomal DNA. Twenty samples of ectomycorrhizae from each visually unidentified morphotype were selected for molecular identification.

PCR reactions aimed at amplifying the nuclear ITS ribosomal region were conducted using the fungi-specific primers ITS1F (5' CTT GGT CAT TTA GAG GAA GTA A 3'; Gardes \& Bruns 1993) and the basidiomycetes-specific ITS4B (5'- CAG GAG ACT TGT ACA CGG TCC AG - 3'; Gardes $\&$ Bruns 1993). The PCR reactions were conducted in a reaction mix of $20 \mu \mathrm{l}$ containing: $10 \mu \mathrm{l}$ of $(2 \times)$ KAPA2G Robust HotStart ReadyMix ${ }^{\circledR}$ (Kapa Biosystems, Boston, USA); (50 ng $\left.\mu^{-1}\right)$ extracted DNA $5 \mu \mathrm{l}$; $(10 \mu \mathrm{M})$ mixture of primers $0.8 \mu \mathrm{l} ;\left(8 \mu \mathrm{g} \mu \mathrm{l}^{-1}\right)$ BSA $2 \mu \mathrm{l} ; 2.2 \mu \mathrm{l}$ of ultrapure $\mathrm{H}_{2} \mathrm{O}$. PCR amplification was performed by initial denaturation for 3 min at $95{ }^{\circ} \mathrm{C}(1$ cycle $), 95{ }^{\circ} \mathrm{C}$ for $15 \mathrm{~s}, 50{ }^{\circ} \mathrm{C}$ for $1 \mathrm{~min}, 72{ }^{\circ} \mathrm{C}$ for $15 \mathrm{~s}(35 \mathrm{cy}$ cles) and $72{ }^{\circ} \mathrm{C}$ for $10 \mathrm{~min}$ ( 1 cycle). PCR reactions were accomplished using a Perkin Elmer GeneAmp $9700^{\circledR}$ thermal cycler. The quality of the resulting PCR product was evaluated by gel electrophoresis. Sequencing of the PCR product was done by the laboratory of the Elizabeth Pharmacon company (Brno, Czech Republic).

Sequence analysis, alignment and the creation of contigs were performed using the $\mathrm{SE}$ QUENCHER ${ }^{\circledR}$ 5.2.4 software (Gene Codes Corporation, Ann Arbor, MI, USA) and ClusTALW2 (Thompson et al. 1994). Sequences with a high degree of similarity were aligned together into contigs. The sequences classified into one homology group were compared with sequences of known origin stored in the NCBI database (National Center for Biotechnology Information, US National Library of Medicine, Bethesda, Maryland, USA) in the BLAST algorithm (Altschul et al. 1997). Taxomony units were identified according to Landeweert et al. (2003) using the identity thresholds described in the work by Hedh et al. (2008).

Chemical analyses of the substrates and needles were carried out on one combined sample for each substrate and substrate $x$ inoculation combination, respectively, in the laboratory of National Forestry Center, Zvolen, Slovakia. For needle analysis, total C and $\mathrm{N}$ were determined by dry combustion $\left(900-1250{ }^{\circ} \mathrm{C}\right)$ and subsequent oxidation-reduction reactions in a $\mathrm{CN}$ analyzer FLASH EA 1112. Concentrations of the other elements were determined after digestion of the ground material in a high pressure microwave in concentrated $\mathrm{HNO}_{3}$. Measurements of $\mathrm{K}, \mathrm{Ca}$ and $\mathrm{Mg}$ were taken using an inductively coupled plasma atomic absorption spectrometer (Thermo iCE 3000) and P spectrophotometrically (PHARO 300) from the $\mathrm{HNO}_{3}$ extract by the ammonium molyb- 
date method. The same methods were used for substrate analysis, except for the preparation of extracting solution by Mehlich method before $\mathrm{P}, \mathrm{K}, \mathrm{Ca}$ and $\mathrm{Mg}$ detection by ICP-AES. The $\mathrm{pH}$ was determined electrometrically in a 1 substrate : 10 water suspension.

The experiment was a three-way classification (substrate, inoculation, block). Experimental plot was one replication of substrate $\times$ inoculation $\times$ block combination $(4$ trays $=$ 324 containers). The growth data, chlorophyll $a$ fluorescence data and percentages of ectomycorrhizae were analyzed by two-way analysis of variance (ANOVA) followed by a Tukey's test $(\mathrm{P}<0.05)$ to test for differences among treatments. To reduce the high variation in the occurrence of ectomycorrhizae within the experimental plots, percentages of ectomycorrhizae were arcsin-transformed prior to statistical analysis. When a significant interaction between the test factors was detected, significance of differences between mean values of parameter of corresponding treatment combination was tested by one-way ANOVA $(\mathrm{P}<0.05)$. ANOVA was carried out using the $\mathrm{SAS}^{\circledR}$ statistical package for PC (SAS Institute Inc., Cary, NC, USA).

\section{Results}

\section{Seedling growth}

Preliminary estimation of seedling growth (after the first growing season) showed a significant influence of both factors tested (substrates and inocula). The enriched substrates (Agro CS and Gramoflor) and inoculation with Ectovit significantly improved mean values of all measured growth variables as compared with the other related treatments (data not shown). Significant substrate $x$ inoculation interaction for stem height and $R C D$ was also detected.

At the end of the second growing season, growth substrate significantly affected all measured growth variables $(\mathrm{P}<0.05)$, except the number of root tips, while ECM inoculation influenced $R D W$ and $S D W / R D W$ ratio only (Tab. 2). Seedlings grown on enriched substrates (Agro CS and Gramoflor) showed mean values for all growth variables (except the number of root tips) significantly higher

Tab. 2 - Analysis of variance (F- and P-values) of the effects of substrate and ectomycorrhizal inoculation on growth parameters and ectomycorrhizal colonization of 2-years-old container-grown Norway spruce seedlings. Degrees of freedom: substrate 2; inoculation 2; block 2; substrate $\times$ inoculation 4 ; error for substrate and inoculation 4 ; error for substrate $\times$ inoculation 8; residual 513; total 539; degrees of freedom for number of root tips and ECM colonization: residual 81 ; total 107 .

\begin{tabular}{lrrrrrr}
\hline \multirow{2}{*}{ Variable } & \multicolumn{2}{c}{ Substrate } & \multicolumn{2}{c}{ Inoculation } & \multicolumn{2}{c}{$\begin{array}{c}\text { Substrate } \times \\
\text { Inoculation }\end{array}$} \\
\cline { 2 - 7 } & \multicolumn{1}{c}{ F } & \multicolumn{1}{c}{ P } & \multicolumn{1}{c}{ F } & \multicolumn{1}{c}{ P } & \multicolumn{1}{c}{ F } & \multicolumn{1}{c}{ P } \\
\hline Root collar diameter & 821.19 & 0.001 & 6.16 & 0.060 & 131.25 & 0.001 \\
Stem height & 7853.66 & 0.001 & 5.98 & 0.063 & 86.32 & 0.001 \\
Shoot dry weight & 2387.26 & 0.001 & 1.94 & 0.258 & 19.07 & 0.001 \\
Root dry weight & 392.50 & 0.001 & 10.04 & 0.028 & 63.98 & 0.001 \\
Total dry weight & 1854.64 & 0.001 & 2.98 & 0.161 & 28.06 & 0.001 \\
Shoot/root dry weight & 13.29 & 0.017 & 18.28 & 0.010 & 3.51 & 0.062 \\
Number of root tips & 0.02 & 0.983 & 0.26 & 0.781 & 4.21 & 0.046 \\
Ectomycorrhizal colonization & 4.80 & 0.087 & 4.49 & 0.095 & 1.02 & 0.451 \\
\hline
\end{tabular}

than those grown on non-enriched substrate (Durpeta). Mean values of growth variables of the seedlings grown in the most affecting substrate (AGRO CS or Gramoflor depending on variable) were 2.2 -fold $(R C D)$ up to 4.6-fold $(S D W)$ higher than those of seedlings grown in the Durpeta substrate (Tab. $3)$. Significantly higher values of $S D W$ and $T D W$ were also detected for seedlings grown in Agro CS, as compared with Gramoflor ( $9 \%$ and $8 \%$, respectively). ECM inoculum Ectovit also promoted seedling growth, even though differences between treatments were not significant for most of the growth variables analyzed. Indeed, seedlings inoculated with Ectovit yielded a root biomass significantly higher $(29 \%)$ than those non-inoculated. $S D W / R D W$ of Mycorrhizaroots-inoculated seedlings was significantly lower than those non-inoculated. No other significant differences in seedling growth among inoculation treatments were found.

The results of the ANOVA indicated that a significant $(\mathrm{P}<0.05)$ interaction occurred between substrate and inoculation treatments (Tab. 2). Ectovit-inoculated seedlings grown in non-enriched substrate had mean values of growth variables significantly higher (except for $S D W / R D W$ ) than those of Mycorrhizaroots and the non-inoculated control. In contrast, they had the same (or in some cases even significantly lower) parameter values when grown in enriched substrates (with exception of $R D W$ in Agro CS - Fig. 1). A depressive effect of Ectovit on seedling growth was evident (except for $R C D$ ) especially in Gramoflor. Contrastingly, a positive effect of this inoculum was observed on the number of root tips in this substrate (Fig. 1). Mean values of treatment combinations for stem height and $T D W$ are not shown here, because differences among combinations and their significance broadly overlap those observed for $S D W$ (Fig. 1).

\section{Ectomycorrhiza estimation}

In total, over 46000 spruce root tips were visually evaluated for ECM colonization. The overall colonization rate ranged from 73 to $80 \%$, regardless of analyzed treatments (Tab. 4).

Regarding the morphological diversity of inspected fine roots, three ECM morphotypes were distinguished: (I) black color, monopodial-pinnate ramification, cylindrical shape, densely grain shiny mantle with emanating hyphae; (II) dark brown, monopodialpinnate ramification, cylindrical shape, shiny or smooth mantle; (III) light orange brown, monopodial-pinnate or monopodial-pyramidal ramification, bent to sinuous shaped, shiny cottony mantle. All treatments revealed almost the same relative abundance of ECM morphotypes. The most common mor-

Tab. 3 - Growth parameters (mean \pm standard error) of 2-years-old container-grown Norway spruce seedlings grown on different substrates inoculated with commercial ectomycorrhizal inocula Ectovit and Mycorrhizaroots. Different letters within substrate and inoculation treatments indicate statistically different values.

\begin{tabular}{|c|c|c|c|c|c|c|c|c|}
\hline Treatment & Type & $\begin{array}{l}\text { Root collar di- } \\
\text { ameter }(\mathrm{mm})\end{array}$ & $\begin{array}{c}\text { Stem height } \\
(\mathrm{cm})\end{array}$ & $\begin{array}{c}\text { Shoot dry } \\
\text { weight (mg) }\end{array}$ & $\begin{array}{c}\text { Root dry } \\
\text { weight (mg) }\end{array}$ & $\begin{array}{c}\text { Total dry } \\
\text { weight (mg) }\end{array}$ & $\begin{array}{c}\text { Shoot/root dry } \\
\text { weight }\end{array}$ & $\begin{array}{l}\text { Root tips } \\
\left(\text { n cm }^{-1}\right)\end{array}$ \\
\hline \multirow[t]{3}{*}{ Substrate } & Agro CS & $2.47 \pm 0.04^{\mathrm{a}}$ & $20.67 \pm 0.30^{\mathrm{a}}$ & $1962 \pm 52^{\mathrm{a}}$ & $960 \pm 28^{a}$ & $2922 \pm 74^{a}$ & $2.16 \pm 0.05^{\mathrm{a}}$ & $16.44 \pm 1.33$ \\
\hline & Gramoflor & $2.52 \pm 0.04^{\mathrm{a}}$ & $20.73 \pm 0.44^{\mathrm{a}}$ & $1798 \pm 65^{\mathrm{b}}$ & $910 \pm 32^{\mathrm{a}}$ & $2708 \pm 92^{b}$ & $2.09 \pm 0.05^{\mathrm{a}}$ & $16.49 \pm 1.44$ \\
\hline & Durpeta & $1.14 \pm 0.04^{\mathrm{b}}$ & $7.87 \pm 0.36^{\mathrm{b}}$ & $426 \pm 41^{\mathrm{c}}$ & $280 \pm 24^{\mathrm{b}}$ & $703 \pm 64^{c}$ & $1.57 \pm 0.08^{\mathrm{b}}$ & $16.91 \pm 1.33$ \\
\hline \multirow[t]{3}{*}{ Inoculation } & Ectovit & $2.14 \pm 0.05^{\mathrm{a}}$ & $17.31 \pm 0.43^{\mathrm{a}}$ & $1509 \pm 60^{\mathrm{a}}$ & $816 \pm 35^{a}$ & $2326 \pm 92^{\mathrm{a}}$ & $1.94 \pm 0.04^{\mathrm{ab}}$ & $17.64 \pm 0.86$ \\
\hline & Mycorrhizaroots & $1.99 \pm 0.08^{\mathrm{a}}$ & $15.92 \pm 0.70^{\mathrm{a}}$ & $1281 \pm 81^{\mathrm{a}}$ & $694 \pm 42^{\mathrm{ab}}$ & $1976 \pm 120^{\mathrm{a}}$ & $1.77 \pm 0.05^{\mathrm{b}}$ & $16.06 \pm 0.77$ \\
\hline & Non-inoculated & $1.99 \pm 0.07^{\mathrm{a}}$ & $15.93 \pm 0.65^{\mathrm{a}}$ & $1382 \pm 84^{\mathrm{a}}$ & $634 \pm 33^{\mathrm{b}}$ & $2018 \pm 115^{\mathrm{a}}$ & $2.10 \pm 0.09^{\mathrm{a}}$ & $16.13 \pm 0.86$ \\
\hline
\end{tabular}


photype (64-70\%) was morphotype II, while the other two morphotypes did not exceed $8 \%$. The relative abundance of non-mycorrhizal short roots ranged from 20 (Agro CS) to $27 \%$ (Durpeta). Neither substrate or inoculation nor treatment interaction had significant effects on ECM colonization.

Based on specific morphological features of the ectomychorrizae, morphotype I was identified as Cenococcum geophilum Fr. Its relative frequency roughly corresponded to the average occurrence of morphotype I ( $6 \%$ of visually evaluated root tips).

Out of the total amplified DNA samples of morphotypes II and III, 27 good-quality ITS sequences $(68 \%)$ were obtained. On the basis of their homology, the analyzed sequences were clustered into four homology groups ( $\geq 95 \%$ homology) which should represent individual taxa. Using the BLAST software, we compared the aligned sequences of each homology group with samples of known origin at the NCBI database. A significant alignment (99-100\%) was found, allowing the identification of each homology group at the species level. Two ectomycorrhizal species were identified by the sequence of amplified ITS region (Tab. 5). The most common fungus was Thelephora terrestris (Ehr.) Ft. (78\% of the obtained ITS sequences), followed by another ECM fungus Laccaria proxima (Boud.) Pat. (15\%). Additionally, a saprophyte species such as Bjerkandera adusta (Willd.: Fr.) P. Karst. was detected (4\%), as well as the yeast Cryptococcus podzolicus (Babeva \& Reshetova) Golubev (5\% of the obtained ITS sequences).

The molecular identification of extracted samples revealed a morphotype-taxon inconsistency for morphotypes II and III. Based on results of the DNA analysis, a clear correspondence between the identified fungus and morphotype was not found. In particular, $T$. terrestris was recognized within both morphotypes (II and III), while the L. proxima was detected in morphotype III only. The most common species $T$. terrestris almost completely dominated within all treatments regardless of the inocula application. Despite the rather scarce abundance of $C$. geophilum and $L$. proxima, both these species were identified in the artificially Ectovit- and $\mathrm{My}$ corrhizaroots-inoculated treatments.

\section{Needle macro-elements concentration}

Tab. 6 reports the concentration at the end of the experiment of the macro-elements analyzed in the needles of inoculated and non-inoculated seedlings grown in the three tested substrates. Needle nutrients concentration followed a similar trend as seedling biomass development. In general, seedlings grown in the enriched substrates (in the case of $\mathrm{N}$ and $\mathrm{K}$ in particular in Agro CS) had higher concentrations of macronutrients as

Tab. 4 - Percentage of ectomycorrhizal morphotypes and total ectomycorrhizal colonization (mean \pm standard error) of 2-years-old container-grown Norway spruce seedlings grown in different substrates inoculated with commercial ectomycorrhizal inocula Ectovit and Mycorrhizaroots.

\begin{tabular}{|c|c|c|c|c|c|c|}
\hline \multirow[b]{2}{*}{$\begin{array}{c}\text { ECM } \\
\text { morphotype }\end{array}$} & \multicolumn{3}{|c|}{ Substrate } & \multicolumn{3}{|c|}{ Inoculation } \\
\hline & Agro CS & Gramoflor & Durpeta & Ectovit & $\begin{array}{c}\text { Mycorrhiza- } \\
\text { roots }\end{array}$ & $\begin{array}{c}\text { Non- } \\
\text { inoculated }\end{array}$ \\
\hline I & $5 \pm 1.4$ & $8 \pm 2.3$ & $5 \pm 1.0$ & $8 \pm 1.7$ & $7 \pm 2.3$ & $1 \pm 1.5$ \\
\hline II & $70 \pm 2.4$ & $64 \pm 4.1$ & $66 \pm 3.1$ & $66 \pm 3.4$ & $67 \pm 4.8$ & $68 \pm 4.4$ \\
\hline III & $5 \pm 1.3$ & $2 \pm 0.9$ & $2 \pm 0.8$ & $3 \pm 0.8$ & $3 \pm 4.1$ & $4 \pm 3.9$ \\
\hline $\begin{array}{c}\text { Total ECM } \\
\text { colonization }\end{array}$ & $80 \pm 2.3$ & $74 \pm 3.6$ & $73 \pm 2.9$ & $75 \pm 2.8$ & $77 \pm 4.4$ & $73 \pm 4.3$ \\
\hline
\end{tabular}
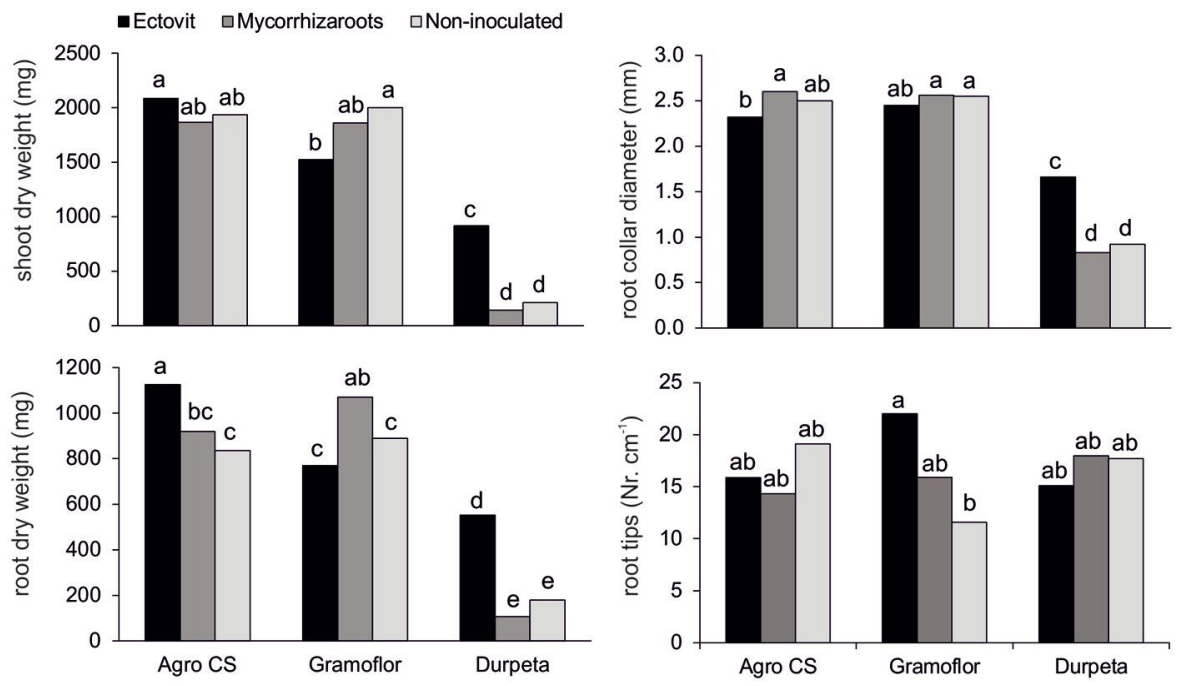

Fig. 1 - Shoot dry weight, root collar diameter, root dry weight and number of root tips of 2years-old container-grown Norway spruce seedlings cultivated in different peat-based substrates inoculated with commercial ectomycorrhizal inocula Ectovit and Mycorrhizaroots. Different letters indicate significantly different values between substrate and ectomycorrhizal inoculum combinations $(P<0.05)$.

compared with seedlings grown in non-enriched substrate, though the only major difference detected was for $\mathrm{Ca}$ concentration. Inoculation treatments in enriched substrates had no distinctive influence on seedling nutrition (at least needle nutrients concentration), with exception of $\mathrm{N}$ in Agro CS. The highest $\mathrm{N}$ level was found for non-inoculated seedlings in Agro CS, and less markedly for the other two substrates. In the non-enriched substrate, needle concentrations of $\mathrm{P}, \mathrm{K}$ and $\mathrm{Ca}$ in Ectovit-inoculated seedlings were higher than those in Mycorrhizaroots-inoculated $(12 \%, 53 \%$ and $9 \%$, respectively) and particularly in non-inoculated seedlings $(17 \%, 77 \%$ and $12 \%$, respectively). Ectovit was very efficient mainly in $\mathrm{K}$-uptake in non-enriched substrate; $\mathrm{K}$ concentration in this treatment combination almost reached the $\mathrm{K}$ level in Agro CS and was higher than in Gramoflor substrate. Magnesium was the element with the most balanced needle concentration regardless of substrate and inoculation treatments.

Tab. 5 - Fungal species identified from the ectomycorrhizal root tips of 2-years-old Norway spruce seedlings. (Vm): visual morphotyping; (Sq): DNA sequencing.

\begin{tabular}{lllllr}
\hline Group & Fungal species & $\begin{array}{l}\text { Method of } \\
\text { identification }\end{array}$ & $\begin{array}{l}\text { Accession } \\
\text { Nr. }\end{array}$ & $\begin{array}{l}\text { BLAST } \\
\text { match ID }\end{array}$ & $\begin{array}{c}\text { Identity } \\
\text { (\%) }\end{array}$ \\
\hline ECM & Thelephora terrestris & $\mathrm{Sq}$ & $\mathrm{KJ} 886932$ & JQ711980.1 & 99 \\
symbiont & Laccaria proxima & $\mathrm{Sq}$ & KJ918763 & JX907813.1 & 100 \\
& Cenococcum geophilum & $\mathrm{Vm}$ & - & - & - \\
\hline Non-ECM & Bjerkandera adusta & $\mathrm{Sq}$ & $\mathrm{KJ} 918764$ & KC176354.1 & 99 \\
species & Cryptococcus podzolicus & $\mathrm{Sq}$ & KJ918765 & FR716534.1 & 99 \\
\hline
\end{tabular}


Tab. 6 - Concentration of macro-elements in needles ( $\mathrm{n}=1$ combined sample) of 2-years-old container-grown Norway spruce seedlings grown on substrates Agro CS, Gramoflor and Durpeta inoculated with commercial ectomycorrhizal inocula Ectovit and Mycorrhizaroots.

\begin{tabular}{|c|c|c|c|c|c|c|}
\hline $\begin{array}{l}\text { Substrate } \times \text { Inoculum } \\
\text { combination }\end{array}$ & $\begin{array}{c}\mathrm{C} \\
(\%)\end{array}$ & $\begin{array}{l}\mathrm{N} \\
(\%)\end{array}$ & $\begin{array}{c}\mathbf{P} \\
\left(\mathrm{mg} \mathrm{kg}^{-1}\right)\end{array}$ & $\begin{array}{c}\mathrm{K} \\
\left(\mathrm{mg} \mathrm{kg}^{-1}\right)\end{array}$ & $\begin{array}{c}\mathrm{Ca} \\
\left(\mathrm{mg} \mathrm{kg}^{-1}\right)\end{array}$ & $\begin{array}{c}\mathrm{Mg} \\
\left(\mathrm{mg} \mathrm{kg}^{-1}\right)\end{array}$ \\
\hline Agro $\mathrm{CS} \times$ Ectovit & 49.8 & 1.25 & 1703 & 7713 & 4885 & 1133 \\
\hline Agro $\mathrm{CS} \times$ Mycorrhizaroots & 51.1 & 1.68 & 1821 & 7625 & 5358 & 1260 \\
\hline Agro $\mathrm{CS} \times$ Non-inoculated & 52.9 & 1.98 & 1674 & 7413 & 5417 & 1352 \\
\hline Gramoflor $\times$ Ectovit & 51.2 & 1.34 & 1713 & 6338 & 5849 & 1198 \\
\hline Gramoflor $\times$ Mycorrhizaroots & 50.5 & 1.38 & 1839 & 7145 & 5657 & 1255 \\
\hline Gramoflor $\times$ Non-inoculated & 51.0 & 1.46 & 1735 & 6502 & 5720 & 1350 \\
\hline Durpeta $\times$ Ectovit & 51.5 & 1.06 & 1527 & 7483 & 2924 & 1104 \\
\hline Durpeta $\times$ Mycorrhizaroots & 48.6 & 1.00 & 1359 & 4885 & 2681 & 1030 \\
\hline Durpeta $\times$ Non-inoculated & 52.6 & 1.08 & 1309 & 4232 & 2608 & 1069 \\
\hline
\end{tabular}

Chlorophyll a fluorescence

As for chlorophyll $a$ fluorescence parameters, a pattern similar to that observed for growth variables was observed, though most differences were not significant (Tab. 7). Seedlings grown in enriched substrates had

means of the fluorescence parameters analyzed higher than seedlings grown in nonenriched substrates, except for variables $F v / F m$ and $F v / F 0$. Significant differences in $T f m, R C / A B S$ and $V j$ were also found among substrates (Tab. 7, Tab. 8). Higher values of

Tab. 7 - Analysis of variance (F- and P-values) of the effects of substrate and commercial ectomycorrhizal inoculation on chlorophyll $a$ fluorescence parameters of 2-years-old container-grown Norway spruce seedlings. Degrees of freedom: substrate 2; inoculation 2; block 2 ; substrate $\times$ inoculation 4 ; error for substrate and inoculation 4 ; error for substrate $\times$ inoculation 8; residual 297; total 323.

\begin{tabular}{lcccccc}
\hline \multirow{2}{*}{ Parameter } & \multicolumn{2}{c}{ Substrate } & \multicolumn{2}{c}{ Inoculation } & \multicolumn{2}{c}{ Substrate $\times$ Inoculation } \\
\cline { 2 - 7 } & F & P & F & P & F & P \\
\hline$F 0$ & 4.97 & 0.082 & 0.93 & 0.467 & 0.24 & 0.911 \\
$F m$ & 2.75 & 0.178 & 1.68 & 0.295 & 0.91 & 0.501 \\
$F v$ & 0.56 & 0.612 & 2.84 & 0.171 & 2.74 & 0.105 \\
$F v / F m$ & 0.68 & 0.556 & 4.51 & 0.094 & 2.38 & 0.138 \\
$T f m$ & 9.09 & 0.033 & 0.20 & 0.825 & 0.39 & 0.812 \\
Area & 6.79 & 0.052 & 0.33 & 0.739 & 3.41 & 0.066 \\
$R C / A B S$ & 9.98 & 0.028 & 0.63 & 0.578 & 9.31 & 0.004 \\
$F v / F 0$ & 0.38 & 0.707 & 3.96 & 0.113 & 2.81 & 0.100 \\
$V j$ & 8.45 & 0.037 & 0.71 & 0.544 & 6.07 & 0.015 \\
$P I$ & 3.01 & 0.159 & 1.70 & 0.292 & 6.20 & 0.014 \\
\hline
\end{tabular}

fluorescence parameters were observed in Ectovit-inoculated seedlings as compared with Mycorrhizaroots- and non-inoculated seedlings, though their differences were not statistically supported. Significant interactions $(\mathrm{P}<0.05)$ between substrate and inoculation treatments were found (Tab. 7). In the non-enriched substrate, values of $R C / A B S$ and $P I$ parameters were significantly higher in Ectovit- than in Mycorrhizaroots-inoculated seedlings (Fig. 2), whereas there were no significant differences between inoculation treatments within both enriched substrates. Moreover, seedlings inoculated with Mycorrhizaroots grown in the enriched substrates had values of $R C / A B S, V j$ and $P I$ parameters significantly higher than those grown in non-enriched substrate; the other two inoculation treatments did not differ between substrates (Fig. 2).

\section{Discussion}

Our results show that the peat-based enriched substrates Agro CS and Gramoflor clearly provided better conditions for development of container-grown Norway spruce seedlings than the pure-peat substrate Durpeta. Such evidence was supported by the enhanced growth and higher physiological parameters of seedlings grown in enriched substrates, as well as by the higher concentration of macronutrients in their needles. A number of studies confirmed that admixture of well-selected components to the peat can substantially improve physical properties of growth substrates and stimulate seedling growth (Heiskanen 1993, Bernier \& Gonzalez 1995, Bakry et al. 2013). In our experiment, a positive effect on nutrient uptake and biomass production of seedlings could be due to the admixture of several components to the enriched substrates, along with the peat type and the degree of humification. However, despite the asserted nutrient en-

Tab. 8 - Chlorophyll $a$ fluorescence parameters (mean \pm standard error) of 2-years-old container-grown Norway spruce seedlings grown in different peat-based substrates inoculated with commercial ectomycorrhizal inocula Ectovit and Mycorrhizaroots. $(F 0)$ : initial fluorescence; $(F m)$ : maximum fluorescence; $(F v)=F m-F 0$, variable fluorescence; $(F v / F m)$ : maximal photochemical efficiency of PSII; $(T f m)$ : time of reaching maximum fluorescence; (Area): area above the fluorescence curve; $(R C / A B S)$ : density of reaction centers; $(F v / F 0)$ : competitive non-photochemical processes in PS II in dark-adapted state; $(V j)$ : relative variable fluorescence at time $2 \mathrm{~ms}$ after start of light pulse; $(P I)$ : performance index for the photochemical activity. Different letters within substrate and inoculation treatments indicate statistically different values.

\begin{tabular}{|c|c|c|c|c|c|c|c|c|c|c|c|}
\hline Factor & Treatment & FO & $F m$ & $F v$ & $F v / F m$ & $T f m$ & Area & $R C / A B S$ & $F v / F 0$ & $V j$ & $P I$ \\
\hline \multirow{3}{*}{ 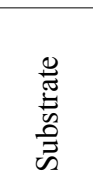 } & Agro CS & $0.29 \pm 0.02^{\mathrm{a}}$ & $0.89 \pm 0.03^{\mathrm{a}}$ & $0.60 \pm 0.01^{\mathrm{a}}$ & $0.71 \pm 0.01^{\mathrm{a}}$ & $543 \pm 14^{\mathrm{ab}}$ & $33945 \pm 1480^{\mathrm{a}}$ & $2.33 \pm 0.06^{\mathrm{a}}$ & $2.98 \pm 0.10^{\mathrm{a}}$ & $0.76 \pm 0.01^{\mathrm{a}}$ & $5.83 \pm 0.31^{\mathrm{a}}$ \\
\hline & Gramoflor & $0.26 \pm 0.02^{\mathrm{a}}$ & $0.84 \pm 0.03^{\mathrm{a}}$ & $0.59 \pm 0.01^{\mathrm{a}}$ & $0.72 \pm 0.01^{\mathrm{a}}$ & $560 \pm 14^{\mathrm{a}}$ & $35243 \pm 2193^{a}$ & $2.33 \pm 0.05^{\mathrm{a}}$ & $3.13 \pm 0.09^{\mathrm{a}}$ & $0.75 \pm 0.01^{\mathrm{ab}}$ & $5.95 \pm 0.25^{\mathrm{a}}$ \\
\hline & Durpeta & $0.20 \pm 0.01^{\mathrm{a}}$ & $0.75 \pm 0.02^{\mathrm{a}}$ & $0.55 \pm 0.01^{\mathrm{a}}$ & $0.72 \pm 0.01^{\mathrm{a}}$ & $464 \pm 13^{b}$ & $25709 \pm 1825^{\mathrm{a}}$ & $1.90 \pm 0.06^{\mathrm{b}}$ & $2.99 \pm 0.08^{\mathrm{a}}$ & $0.71 \pm 0.01^{\mathrm{b}}$ & $4.63 \pm 0.23^{\mathrm{a}}$ \\
\hline \multirow{3}{*}{ 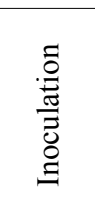 } & Ect & $0.25 \pm$ & $0.87 \pm$ & $0.61 \pm 0.01^{\mathrm{a}}$ & $0.73 \pm 0.01^{\mathrm{a}}$ & $528 \pm 14^{\mathrm{a}}$ & 32850 & $2.22 \pm 0.05^{\mathrm{a}}$ & $3.16 \pm 0.09^{\mathrm{a}}$ & $0.75 \pm 0.01^{\mathrm{a}}$ & $5.67 \pm 0.24^{\mathrm{a}}$ \\
\hline & $\begin{array}{l}\text { Mycorrhi- } \\
\text { zaroots }\end{array}$ & $0.26 \pm 0.02^{\mathrm{a}}$ & $0.82 \pm 0.03^{\mathrm{a}}$ & $0.56 \pm 0.02^{\mathrm{a}}$ & $0.70 \pm 0.01^{\mathrm{a}}$ & $520 \pm 14^{\mathrm{a}}$ & $30926 \pm 1731^{\mathrm{a}}$ & $2.15 \pm 0.07^{\mathrm{a}}$ & $2.93 \pm 0.10^{\mathrm{a}}$ & $0.74 \pm 0.01^{\mathrm{a}}$ & $5.44 \pm 0.32^{\mathrm{a}}$ \\
\hline & $\begin{array}{l}\text { Non-ino- } \\
\text { culated }\end{array}$ & $0.24 \pm 0.02^{\mathrm{a}}$ & $0.80 \pm 0.03^{\mathrm{a}}$ & $0.56 \pm 0.02^{\mathrm{a}}$ & $0.72 \pm 0.01^{\mathrm{a}}$ & $518 \pm 14^{\mathrm{a}}$ & $30940 \pm 1690^{\mathrm{a}}$ & $2.18 \pm 0.06^{\mathrm{a}}$ & $3.01 \pm 0.09^{\mathrm{a}}$ & $0.74 \pm 0.01^{\mathrm{a}}$ & $5.27 \pm 0.24^{\mathrm{a}}$ \\
\hline
\end{tabular}


Fig. 2 - Chlorophyll $a$ fluorescence parameters $R C / A B S, V j, P I$ of 2years-old container-grown Norway spruce seedlings cultivated in different peat-based substrates inoculated with commercial ectomycorrhizal inocula Ectovit and Mycorrhizaroots. Different letters indicate significantly different values between substrate and ectomycorrhizal inoculum combinations $(P<0.05)$.
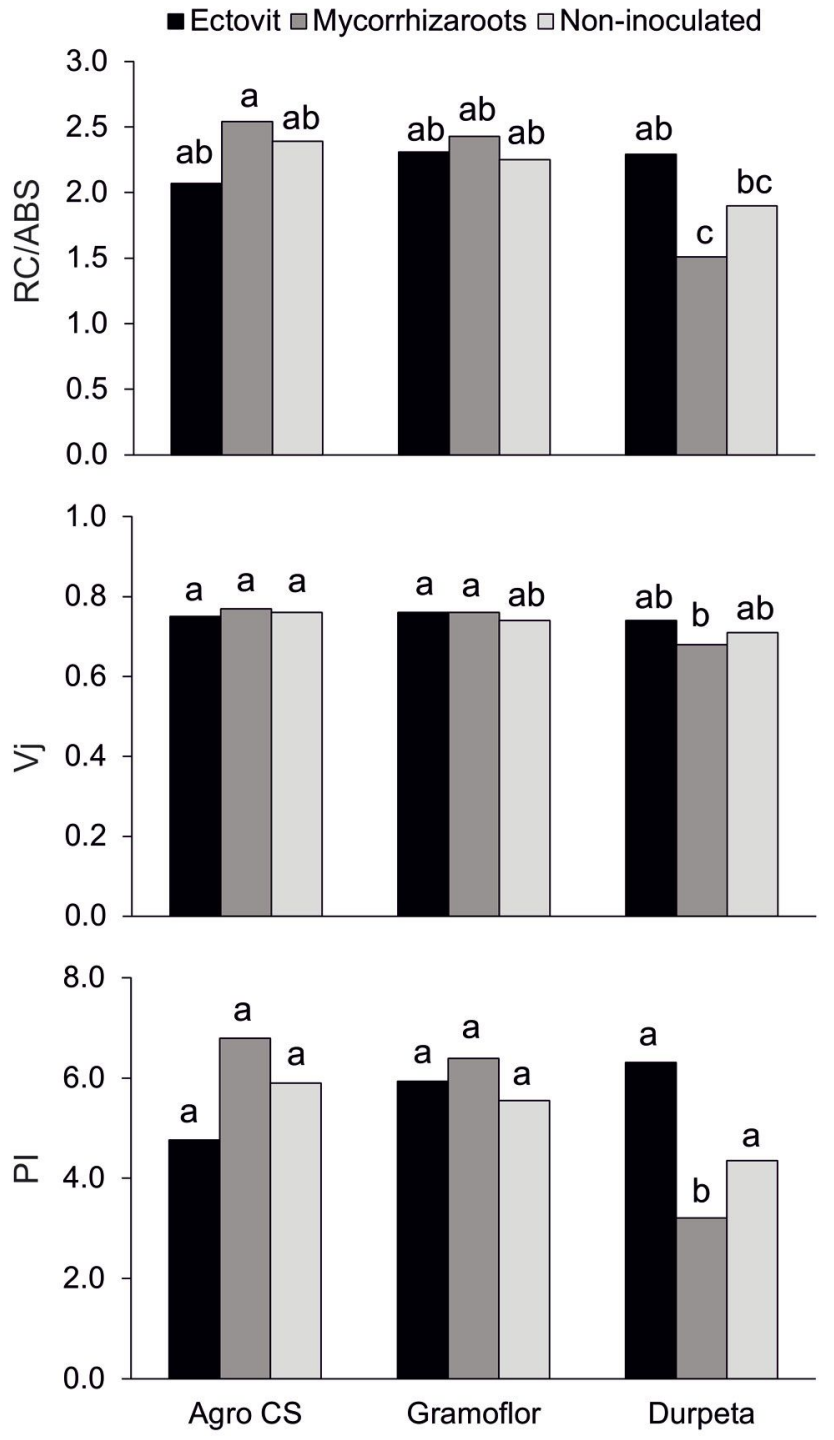

richment of the commercial substrates Agro $\mathrm{CS}$ and Gramoflor, their concentration in $\mathrm{N}$ and $\mathrm{K}$ was similar that of the non-enriched Durpeta substrate after chemical analysis. This finding is likely to be due to the diverse origin of substrates and their level of decomposition, leading to differences in nutrient content and physical properties. No direct relationship between the substrate and nutrients concentration in the needles was found. On the contrary, macro-elements in seedling foliage reflected the trend already observed for growth, with higher concentrations found in seedlings on enriched substrates. However, these seedlings showed nutrient concentrations in the needles falling within the range of values recommended by Rikala (2002), except for $\mathrm{Ca}$ which was slightly higher, while Durpeta seedlings showed lower values out of the above range. Nevertheless, a positive effect of Ectovit inoculation on the needle $\mathrm{P}$ and $\mathrm{K}$ concentrations of Durpeta seedlings was observed. A similar positive influence of Ectovit on needle nutri- ent concentration of Norway spruce cuttings was described by Repáč et al. (2011b).

Other chemical characteristics may directly affect the availability of macro- and microelements, as well as the combined effect of physical and chemical properties of substraor alkalinity of the growth medium is of great importance for the availability of nutrients in the soil solution (Brian et al. 1999). The low pH (3.4) of the Durpeta substrate could have caused a weaker seedling development, while the enriched substrates Agro CS ( $\mathrm{pH} 4.3$ ) and Gramoflor ( $\mathrm{pH} 4.6)$ had recommended value of $\mathrm{pH}(4.0-5.0)$, thus providing optimal conditions for growth of coniferous tree species (Rikala \& Jozefek 1990). However, some authors reported that the maximum availability of nutrients for seedlings grown on organic substrates is reached at $\mathrm{pH}>5.5$ (Bunt 1988, Landis et al. 1990). Furthermore, the high $\mathrm{C} / \mathrm{N}$ ratio of Durpeta substrate in this study could have caused the immobilization of certain nutrites (Rincón et al. 2007). Indeed, the acidity ents by microorganisms (Kakei \& Clifford 2000 , Rincón et al. 2005), negatively affecting the growth of spruce seedlings.

Positive effects of the ECM inoculation on the development of bareroot and containergrown seedlings have been reported in Norway spruce (Kropáček \& Cudlín 1989, Repáč 1996, Brunner \& Brodbeck 2001) and several pine species (Duñabeitia et al. 2004, Rincón et al. 2007). However, in other studies inoculation did not affect or even reduce seedling growth (Rincón et al. 2005, Repáč 2007, Díaz et al. 2009). Seedling response to inoculation can be affected by several factors, including the type of inoculum, inoculation pattern, interspecific and intraspecific host-fungus variation, environmental conditions, and seedling production practices (Rincón et al. 2007, Repáć 2011). In our experiment the significant interaction found between substrate and inoculation indicated that seedlings' development is affected by both factors. Indeed, the inoculation with Ectovit promoted the growth and physiological state of seedlings grown in Durpeta substrate. Similarly, significant interaction substrate $\times$ ECM inoculation resulted in enhanced growth of seedlings in Pinus sylvestris (Baar \& Elferink 1996), Pinus pinea (Rincón et al. 2005) and Picea abies (Repáč 2007).

Several studies showed that growth substrate, especially nutrient content, and ECM inoculation considerably affect $S D W, R D W$ and thereby $S D W / R D W$ in Norway spruce seedlings (Repáč 1996, Brunner \& Brodbeck 2001, Flykt et al. 2008). In this experiment, the enriched substrates Agro CS and Gramoflor stimulated the growth of aboveground part of seedlings, while the inoculation increased the root biomass, particularly in Mycorrhizaroots-inoculated seedlings. This finding is in accordance with the results reported by Repáč (1996) and Flykt et al. (2008), but is in contradiction with those of Brunner \& Brodbeck (2001). Significantly higher values of $S D W / R D W$ in peat-based substrates, as compared with compost-based substrates, were also reported (Repáč 2007). Contrastingly, Quoreshi \& Timmer (2000) and Fan et al. (2004) did not observe significant effects of fertilization and inoculation on the $S D W / R D W$ ratio. Overall, the lower $S D W / R D W$ observed in this experiment (in particular for Mycorrhizaroots-inoculated seedlings) may contribute to better field performance of seedlings, especially on dry sites (Davis \& Jacobs 2005, Vaario et al. 2009).

Visual inspection of the root systems confirmed the abundant root colonization by ECM fungi. The high root colonization observed in this study (overall $75 \%$, irrespective of the treatment) is common in artificially inoculated seedlings grown under controlled conditions (Khasa et al. 2001, Gonza- 
lez-Ochoa et al. 2003, Flykt et al. 2008). As for the morphology of ectomycorrhizae, our results suggest a low degree of morphological diversity among treatments, as most of the root tips were classified in the ECM morphotype II. However, the similarity of morphotypes II and III could have potentially led to the underestimation of the abundance of morphotype III.

The fungal community associated with the analyzed spruce seedlings was rather homogeneous, as expected for early successional stages of ECM (Püttsepp et al. 2004). Successful colonization was detected by three ECM fungi, but most ectomycorrhizae (irrespective of the inoculation) were formed by the soil-borne ECM fungus Thelephora terrestris $\mathrm{Fr}$., while the other two (C. geophilum and L. proxima) did not exceed $15 \%$ in abundance. However, the method used for their identification did not allow a direct confirmation of their origin from the applied inocula.

The poor ECM species composition associated with the analyzed spruce roots did not reflect the species-rich mixture contained in the applied biological additives. The low colonization effectiveness of tested commercial inocula was most likely the result of their diminished competitive ability as compared to soil-borne ECM species. Natural colonization of $P$. abies by soil-borne fungi in nursery conditions was reported by several authors (Tammi et al. 2001, Trocha et al. 2006, Pietras et al. 2013), especially Thelephora terrestris, regarded as the main competitor of introduced ECM fungi (Browning \& Whitney 1993, Gonzalez-Ochoa et al. 2003, Hilszczanska et al. 2008). Moreover, the application of fungicides and fertilizers during the growing period likely had a negative effect on beneficial ECM fungi (Smaill \& Walbert 2013).

A significant effect of hydrogel on physical properties of peat was reported by Heiskanen (1995). According to Chirino et al. (2011), addition of hydrogel to peat-based substrates increased water-holding capacity and positively affected shoot height of containerized Quercus suber seedlings. By contrast, no effect of Ectovit on rooting and biomass production of Norway spruce cuttings was found by Repáč et al. (2011b). Moreover, the influence of field inoculation with Ectovit on outplanting performance of Norway spruce seedlings was reported as negligible (Holuša et al. 2009, Pešková \& Tuma 2010, Repáč et al. 2011a).

Measurement of chlorophyll $a$ fluorescence is non-destructive, non-invasive and a reliable tool for assessing the response of forest tree seedlings to different substrate properties and ECM inoculation treatments (Bois et al. 2006, Correa et al. 2008, Jamnická et al. 2013, Mancilla-Leyton et al. 2013). Jamnická et al. (2013) reported a chronic pho- toinhibition of European beech seedlings under drought treatment, while no significant changes in maximal quantum efficiency $(\mathrm{Fv} / \mathrm{Fm})$ were found as compared to irrigated control after hydrogel application. MancillaLeyton et al. (2013) found significant differences in $F v / F m$ between cork oak seedlings grown on nutrient-poor and nutrient-rich substrates. Vodnik \& Gogala (1994) reported higher levels of chlorophyll and carotenoids in needles of Picea abies seedlings inoculated with ECM fungi as compared with the control treatment.

In this study, chlorophyll $a$ fluorescence parameters (mainly $R C / A B S, V j$ and $P I$ ) reflected the observed differences in seedlings' growth among the substrate and inoculation treatments. Mean values of $F v / F m(0.70-$ 0.73 ) indicated a slightly lower level of photosynthesis in the investigated seedlings, as compared with the literature (Maxwell \& Johnson 2000).

\section{Conclusion}

Evaluation of growth and physiological parameters of 2-year-old container-grown Norway spruce seedlings showed different effects of the tested peat substrates (differing in origin, composition and thus in physical and chemical properties) on seedling development. Results indicate that the enriched peat-based substrates tested is a suitable potting substrate for Norway spruce seedlings. Significant effects of the interaction substrate $\times$ inoculation on several growth and physiological parameters also indicates a distinctive influence of commercial ECM inocula on seedling development. Ectovit inoculum applied as hydrogel stimulated seedling growth in the non-enriched pure peat substrate. This effect was more likely induced by the particular physical and chemical properties of the inoculum rather than to nutritional or non-nutritional effects of the ECM fungi inoculated. Inoculation did not lead to the formation of specific ectomycorrhizae on seedlings, most probably because of the massive competition of the soil-borne ECM fungus Thelephora terrestris.

The results reported in this study may be useful for the improvement of nursery practices in Norway spruce, aimed at the production of high-quality seedlings with enhanced rooting by ectomycorrhizal fungi.

\section{Acknowledgements}

We thank Dr. Alistair Pfeifer for the improvement of English, two anonymous reviewers for their comments on an earlier version of the manuscript, Mrs. Jana Povalačová and Mr. Samuel Kozánek for their technical assistance. This work was financially supported by the Scientific Grant Agency of Ministry of Education SR and Slovak Academy of Sciences (project VEGA $1 / 521 / 13)$.

\section{References}

Agerer R (2002). Color atlas of Ectomycorrhizae $\left(12^{\text {th }}\right.$ edn). Einhorn Verlag, Schwäbisch Gmünd, Germany.

Agerer R, Rambold G (2011). DEEMY - an information system for characterization and determination of Ectomycorrhizae. München, Germany. [online] URL: http://www.deemy.de

Altschul SF, Madden TL, Schäffer AA, Zhang J, Zhang Z, Miller W, Lipman DJ (1997). Gapped BLAST and PSI-BLAST: a new generation of protein database search programs. Nucleic Acids Research 25: 3389-3402. - doi: 10.1093/nar/25. 17.3389

Baar J, Elferink MO (1996). Ectomycorrhizal development on Scots pine (Pinus sylvestris L.) seedlings in different soils. Plant and Soil 179: 287-292. - doi: 10.1007/BF00009339

Bakry M, Lamhamedi MS, Caron J, Bernier PY, El Abidine AZ, Stowe DC, Margolis HA (2013). Changes in the physical properties of two Acacia compost-based growing media and their effects on carob (Ceratonia siliqua L.) seedling development. New Forests 44: 827-847. - doi: 10.10 07/s11056-013-9368-6

Bernier PY, Gonzalez A (1995). Effects of the physical properties of Sphagnum peat on the nursery growth of containerized Picea mariana and Picea glauca seedlings. Scandinavian Journal of Forest Research 10: 176-183. - doi: 10.1080/02827589509382882

Bois G, Bigras FJ, Bertrand A, Piché Y, Fung MYP, Khasa DP (2006). Ectomycorrhizal fungi affect the physiological responses of Picea glauca and Pinus banksiana seedlings exposed to an $\mathrm{NaCl}$ gradient. Tree Physiology 26: $1185-$ 1196. - doi: 10.1093/treephys/26.9.1185

Brestič M, Zivčák M (2013). PSII fluorescence techniques for measurement of drought and high temperature stress signal in plants: protocols and applications. In: "Molecular stress physiology of plants" (Rout GR, Das AB eds). Springer, Dordrecht, Netherlands, pp. 87-131. - doi: 10.1007/ 978-81-322-0807-5 4

Brian J, Kriedemann PE, Turnbull CGN (1999). Plants in action. Adaptation in nature, performance in cultivation. Macmillan Education, Melbourne, Australia, pp. 664. [online] URL: http://books.google.com/books?id=chWs4ewSzp EC

Browning MHR, Whitney RD (1993). Infection of containerized jack pine and black spruce by Laccaria species and Thelephora terrestris and seedling survival and growth after outplanting. Canadian Journal of Forest Research 23: 330333. - doi: 10.1139/x93-046

Brunner I, Brodbeck S (2001). Response of mycorrhizal Norway spruce seedlings to various nitrogen loads and sources. Environmental Pollution 114: 223-233. - doi: 10.1016/S0269-7491 (00)00219-0

Bunt AC (1988). Media and mixes for containergrown plants. A manual on the preparation and use of growing media for pot plants. Unwin Hyman Ltd., London, UK, pp. 309. [online] URL: http://www.cabdirect.org/abstracts/19880352302 
.html

Chirino E, Vilagrosa A, Vallejo VR (2011). Using hydrogel and clay to improve the water status of seedlings for dryland restoration. Plant and Soil 344: 99-110. - doi: 10.1007/s11104-011-0730-1 Correa A, Strasser RJ, Martins-Loução MA (2008). Response of plants to ectomycorrhizae in N-limited conditions: which factors determine its variation? Mycorrhiza 18: 413-427. - doi: 10.1007/s00572-008-0195-0

Courty PE, Buée M, Diedhiou AG, Frey-Klett P, Le Tacon F, Rineau F, Turpault MP, Uroz S, Garbaye J (2010). The role of ectomycorrhizal communities in forest ecosystem processes: new perspectives and emerging concepts. Soil Biology and Biochemistry 42: 679-698. - doi: 10.10 16/j.soilbio.2009.12.006

Davis AS, Jacobs DF (2005). Quantifying root system quality of nursery seedlings and relationship to outplanting performance. New Forests 30: 295-311. - doi: 10.1007/s11056-005-7480-y Díaz G, Carrillo C, Honrubia M (2009). Production of Pinus halepensis seedlings inoculated with the edible fungus Lactarius deliciosus under nursery conditions. New Forests 38: 215227. - doi: 10.1007/s11056-009-9142-y

Duñabeitia MK, Hormilla S, Garcia-Plazaola JI, Txarterina K, Arteche U, Becerril JM (2004). Differential responses of three fungal species to environmental factors and their role in the mycorrhization of Pinus radiata D. Don. Mycorrhiza 14: 11-18. - doi: 10.1007/s00572-003-0270-5

Esen D, Yildiz O, Esen U, Edis S, Çetintas C (2012). Effects of cultural treatments, seedling type and morphological characteristics on survival and growth of wild cherry seedlings in Turkey. iForest 5: 283-289. - doi: 10.3832/ifor0639005

Fan Z, Moore JA, Wenny DL (2004). Growth and nutrition of container-grown ponderosa pine seedlings with controlled-release fertilizer incorporated in the root plug. Annals of Forest Science 61: 117-124. - doi: 10.1051/forest:2004002

Flykt E, Timonen S, Pennanen T (2008). Variation of ectomycorrhizal colonisation in Norway spruce seedlings in Finnish forest nurseries. Silva Fennica 42: 571-585. - doi: 10.14214/sf.2 34

Garbaye J, Churin JL (1997). Growth stimulation of young oak plantations inoculated with the ectomycorrhizal fungus Paxillus involutus with special reference to summer drought. Forest Ecology and Management 98: 221-228. - doi 10.1016/S0378-1127(97)00105-9

Gardes M, Bruns TD (1993). ITS primers with enhanced specificity for basidiomycetes - application to the identification of mycorrhizae and rusts. Molecular Ecology 2: 113-118. - doi: 10.1111/j.1365-294X.1993.tb00005.x

Gonzalez-Ochoa AI, Heras J, Torres P, SánchezGómez E (2003). Mycorrhization of Pinus halepensis Mill. and Pinus pinaster Aiton seedlings in two commercial nurseries. Annals of Forest Science 60: 43-48. - doi: 10.1051/forest:20020 72

Hedh J, Wallander H, Erland S (2008). Ectomy- corrhizal mycelial species composition in apatite amended and non-amended mesh bags buried in a phosphorus-poor spruce forest. Mycological Research 112: 681-688. - doi: 10.1016/j.mycres. 2007.11.008

Heiskanen J (1993). Favourable water and aeration conditions for growth media used in containerized tree seedling production: a review. Scandinavian Journal of Forest Research 8: 337 358. - doi: 10.1080/02827589309382782

Heiskanen J (1995). Physical properties of twocomponent growth media based on Sphagnum peat and their implications for plant-available water and aeration. Plant and Soil 172: 45-54. doi: 10.1007/BF00020858

Heiskanen J (2013). Effects of compost additive in sphagnum peat growing medium on Norway spruce container seedlings. New Forests 44: 101118. - doi: 10.1007/s11056-011-9304-6

Hilszczanska D, Malecka M, Sierota Z (2008). Changes in nitrogen level and mycorrhizal structure of Scots pine seedlings inoculated with Thelephora terrestris. Annals of Forest Science 65 (409): 1-6. - doi: 10.1051/forest:2008020

Holuša J, Pešková V, Vostrá L, Pernek M (2009). Impact of mycorrhizal inoculation on spruce seedling: comparisons of a 5-year experiment in forests infested by honey fungus. Periodicum Biologorum 111: 413-417. [online] URL: http:// hrcak.srce.hr/index.php?show=clanak\&id_clana $\mathrm{k}$ jezik $=73850$

Ineichen K, Wiemken V (1992). Changes in the fungus-specific, soluble-carbohydrate pool during rapid and synchronous ectomycorrhiza formation of Picea abies with Pisolithus tinctorius. Mycorrhiza 2: 1-7. - doi: 10.1007/BF00206277 Jamnická G, Ditmarová L, Kurjak D, Kmet J, Pšidová E, Macková M, Gömöry D, Strelcová K (2013). The soil hydrogel improved photosynthetic performance of beech seedlings treated under drought. Plant Soil and Environment 59: 446-451. [online] URL: http://agriculturejournals.cz/publicFiles/102483.pdf

Juntunen ML, Rikala R (2001). Fertilization practice in Finnish forest nurseries from the standpoint of environmental impact. New Forests 21: 141-158. - doi: 10.1023/A:1011837800185

Kakei M, Clifford PE (2000). Long-term effects of lime application on ${ }^{15} \mathrm{~N}$ availability to Sitka spruce seedlings growing in pots containing peat soils. Forestry 73: 393-401. - doi: 10.1093/fore stry/73.4.393

Khasa PD, Sigler L, Chakravarty P, Dancik BP, Erickson L, McCurdy D (2001). Effect of fertilization on growth and ectomycorrhizal development of container-grown and bare-root nursery conifer seedlings. New Forests 22: 179-197. doi: 10.1023/A:1015674921878

Kropáček K, Cudlín P (1989). Preparation of granulated mycorrhizal inoculum and its use in forest nurseries. In: "Interrelationships between microorganisms and plants in soil" (Vančura V, Kunc F eds). Academia, Prague, Czech Republic, pp. 177-182. - doi: 10.1016/S0166-2481(08) 70212-5

Kropp BR, Langlois CG (1990). Ectomycorrhizae in reforestation. Canadian Journal of Forest Research 20: 438-451. - doi: 10.1139/x90-061

Landeweert R, Leeflang P, Kuyper TW, Hoffland E, Rosling A, Wernars K, Smit E (2003). Molecular identification of ectomycorrhizal mycelium in soil horizons. Applied Environmental Microbiology 69: 327-333. - doi: 10.1128/AEM.69.1. 327-333.2003

Landis TD, Tinus RW, McDonald SE, Barnett JP (1990). The container tree nursery manual. Containers and growth media (vol. 2). USDA Forest Service, Washington, USA, pp. 87.

Le Tacon F, Bouchard D, Perrin R (1986). Effects of soil fumigation and inoculation with pure culture of Hebeloma cylindrosporum on survival, growth and ectomycorrhizal development of Norway spruce and douglas fir seedlings. European Journal of Forest Pathology 16: 257-265. doi: 10.1111/j.1439-0329.1986.tb00190.x

Lehto T (1994). Effects of soil $\mathrm{pH}$ and calcium on mycorrhizas of Picea abies. Plant and Soil 163: 69-75. - doi: 10.1007/BF00033942

Mancilla-Leyton JM, Cambrolle J, Figueroa ME, Vicente AM (2013). Growth and survival of cork oak (Quercus suber) seedlings after simulated partial cotyledon consumption under different soil nutrient contents. Plant and Soil 370: 381392. - doi: 10.1007/s11104-013-1646-8

Marx DH, Bryan WC, Cordell CE (1976). Growth and ectomycorrhizal development of pine seedlings in nursery soils infested with the fungal symbiont Pisolithus tinctorius. Forest Science 22: 91-100. [online] URL: http://www.ingentaconnect.com/content/saf/fs/1976/00000022/0000 0001/art00016

Maxwell K, Johnson GN (2000). Chlorophyll fluorescence - a practical guide. Journal of Experimental Botany 51: 659-668. - doi: 10.1093/jex bot $/ 51.345 .659$

Mortier F, Le Tacon F, Garbaye J (1988). Effect of inoculum type and inoculation dose on ectomycorrhizal development, root necrosis and growth of Douglas fir seedlings inoculated with Laccaria laccata in a nursery. Annals of Forest Science 45: 301-310. - doi: 10.1051/forest:1988 0401

Moser M (1960). Die Gattung Phlegmacium (Schleimköpfe) [Subgenus Phlegmacium (Cortinarius)]. Verlag Julius Klinkhardt, Bad Heilbrunn, Germany, pp. 440. [in German]

Nilsson U, Orlander G (1995). Effects of regeneration methods on drought damage to newly planted Norway spruce seedlings. Canadian Journal of Forest Research 25 (5): 790-802. doi: 10.1139/x95-086

Ortega U, Duñabeitia M, Menendez S, GonzalezMurua C, Majada J (2004). Effectiveness of mycorrhizal inoculation in the nursery on growth and water relations of Pinus radiata in different water regimes. Tree Physiology 24 (1): 65-73. doi: 10.1093/treephys/24.1.65

Pešková V, Tuma M (2010). Influence of artificial mycorrhization on development of spruce seedlings at Jablunkov (forest district). Zprávy lesnického výzkumu 55: 211-220. [in Czech with English summary] 
Pietras M, Rudawska M, Leski T, Karlinski L (2013). Diversity of ectomycorrhizal fungus assemblages on nursery grown European beech seedlings. Annals of Forest Science 70 (2): 115 121. - doi: $10.1007 / \mathrm{s} 13595-012-0243-\mathrm{y}$

Püttsepp U, Rosling A, Taylor AFS (2004). Ectomycorrhizal fungal communities associated with Salix viminalis $\mathrm{L}$. and $S$. dasyclados Wimm. clones in a short-rotation forestry plantation. Forest Ecology and Management 196 (2-3): 413424. - doi: 10.1016/j.foreco.2004.04.003

Quoreshi AM, Timmer VR (2000). Early outplanting performance of nutrient-loaded containerized black spruce seedlings inoculated with $\mathrm{Lac}$ caria bicolor: a bioassay study. Canadian Journal of Forest Research 30 (5): 744-752. - doi: 10.1139/x00-003

Repáč I (1996). Inoculation of Picea abies (L.) Karst. seedlings with vegetative inocula of ectomycorrhizal fungi Suillus bovinus (L.:Fr.) O. Kuntze and Inocybe lacera (Fr.) Kumm. New Forests 12 (1): 41-54. - doi: 10.1007/BF000299 81

Repáč I (2007). Ectomycorrhiza formation and growth of Picea abies seedlings inoculated with alginate-bead fungal inoculum in peat and bark compost substrates. Forestry 80 (5): 517-530. doi: 10.1093/forestry/cpm036

Repáć I (2011). Ectomycorrhizal inoculum and inoculation techniques. In: "Diversity and Biotechnology of Ectomycorrhizae" (Rai M, Varma A eds). Soil Biology 25, Springer, Berlin Heidelberg, Germany, pp. 43-63. - doi: 10.1007/978-3642-15196-5_3

Repáč I, Tučeková A, Sarvašová I, Vencurik J (2011a). Survival and growth of outplanted seedlings of selected tree species on the High Tatra Mts. windthrow area after the first growing season. Journal of Forest Science 57: 349-358. [online] URL: http://81.0.228.28/publicFiles/45145. pdf

Repáč I, Vencurik J, Balanda M (2011b). Testing of microbial additives in the rooting of Norway spruce (Picea abies [L.] Karst.) stem cuttings.
Journal of Forest Science 57: 555-564. [online] URL: http://agriculturejournals.cz/publicFiles/54 219.pdf

Rikala R (2002). Metsätaimiopas - taimien valinta ja käsittely tarhalta uudistusalalle [Forest tree guide - seedling selection and processing for the shelter sector reform]. Research Papers no. 881, The Finnish Forest Research Institute, Joensuu, Finland, pp. 107.

Rikala R, Jozefek HJ (1990). Effect of dolomite lime and wood ash on peat substrate and development of tree seedlings. Silva Fennica 24: 323334. - doi: 10.14214/sf.a15586

Rincón A, Parladé J, Pera J (2005). Effects of ectomycorrhizal inoculation and the type of substrate on mycorrhization, growth and nutrition of containerised Pinus pinea L. seedlings produced in a commercial nursery. Annals of Forest Science 62: 817-822. - doi: 10.1051/forest:2005087 Rincón A, Parladé J, Pera J (2007). Influence of the fertilisation method in controlled ectomycorrhizal inoculation of two Mediterranean pines. Annals of Forest Science 64: 577-583. - doi: 10.1051/forest:2007035

Rincón A, Priha O, Sotta B, Bonnet M, Le Tacon F (2003). Comparative effects of auxin transport inhibitors on rhizogenesis and mycorrhizal establishment of spruce seedlings inoculated with Laccaria bicolor. Tree Physiology 23: 785-791. - doi: 10.1093/treephys/23.11.785

Smaill SJ, Walbert K (2013). Fertilizer and fungicide use increases the abundance of less beneficial ectomycorrhizal species in a seedling nursery. Applied Soil Ecology 65: 60-64. - doi: 10.101 6/j.apsoil.2013.01.007

South DB, Harris SW, Barnett JP, Hainds MJ, Gjerstad DH (2005). Effect of container type and seedling size on survival and early height growth of Pinus palustris seedlings in Alabama, USA. Forest Ecology and Management 204: 385-398. doi: $10.1016 /$ j.foreco.2004.09.016

Tammi H, Timonen S, Sen R (2001). Spatiotemporal colonization of Scots pine roots by introduced and indigenous ectomycorrhizal fungi in forest humus and nursery Sphagnum peat microcosms. Canadian Journal of Forest Research 31: 746-756. - doi: 10.1139/x01-011

Thompson JD, Higgins DG, Gibson TJ (1994). CLUSTAL W: improving the sensitivity of progressive multiple sequence alignment through sequence weighting, position-specific gap penalties and weight matrix choice. Nucleic Acids Research 22: 4673-4680. - doi: 10.1093/nar/22.22. 4673

Topić V, Butorac L, Jelić G, Perić S (2006). Influence of container type on growth and development of holm oak (Quercus ilex L.) seedlings in a nursery. Periodicum Biologorum 108: 643-648. [online] URL: http://bib.irb.hr/prikazi-rad?lang= en\&rad=334330

Trocha LK, Rudawska M, Leski T, Dabert M (2006). Genetic diversity of naturally established ectomycorrhizal fungi on Norway spruce seedlings under nursery conditions. Microbial Ecology 52: 418-425. - doi: 10.1007/s00248-006-91 10-4

Vaario LM, Pennanen T, Sarjala T, Savonen EM, Heinonsalo J (2010). Ectomycorrhization of Tricholoma matsutake and two major conifers in Finland - an assessment of in vitro mycorrhiza formation. Mycorrhiza 20: 511-518. - doi: 10.1007/s00572-010-0304-8

Vaario LM, Tervonen A, Haukioja K, Haukioja M, Pennanen T, Timonen S (2009). The effect of nursery substrate and fertilization on the growth and ectomycorrhizal status of containerized and outplanted seedlings of Picea abies. Canadian Journal of Forest Research 39: 64-75. - doi: 10.1139/X08-156

Vodnik D, Gogala N (1994). Seasonal fluctuations of photosynthesis and its pigments in 1-year mycorrhized spruce seedlings. Mycorrhiza 4: 277 281. - doi: 10.1007/BF00206777

Wilson ER, Vitols KC, Park A (2007). Root characteristics and growth potential of container and bare-root seedlings of red oak (Quercus rubra L.) in Ontario, Canada. New Forests 34: 163176. - doi: 10.1007/s11056-007-9046-7 